\title{
EXCHANGE RATE CHANGES, TRADE DEVELOPMENT AND STRUCTURAL ADJUSTMENT IN THE EAST ASIAN ECONOMIES
}

\section{ZHOU XIAOBING \& LIGANG SONG}

Discussion of the relationship between exchange rate movements and the growth of trade in the East Asian economies has drawn renewed attention among economists and policymakers alike since the Asian financial crisis broke out in mid-1997. Understanding the pattern of this relationship may partly explain the occurrence of the financial crisis in these export-oriented economies. Exchange rate movements (large scale depreciations), directly caused by the financial crisis, will shape the way in which the regional economy recovers from the crisis. Discussion of exchange rate policies in the regional economy can be put into the broader context of trade reform and liberalisation. Much can be learned from the experiences of the East Asian economies as they emerge from financial crisis.

The key to understanding the relationship between exchange rate and trade is that changes in exchange rates not only regional currencies against major currencies such as the US dollar and Japanese yen, but also major currencies such as the US dollar vis-à-vis the Japanese yen-have a direct impact on the international competitivenes of developing economies. An understanding of this relationship has important implications for these export-oriented economies with respect to ongoing structural change and adjustment and their economic recovery.

What follows is some preliminary evidence of how the trade performance of the East Asian economies has been related to changes in their exchange rates in the past - particularly in relation to major currencies such as the US dollar and Japanese yen. Some policy implications with respect to the necessity for and direction of structural adjustments in the East Asian economies is discussed, highlighting the relationship between China and other East Asian economies. The East Asia economies are treated as an entity in discussing the 
overall trade performance and changes in exchange rates of the regional economies over the past two to three decades.

\section{EXCHANGE RATEMOVEMENTS, TRADEANDECONOMICGROWTH}

The defining characteristic of the East Asian economy in the past is that the rapid development and growth of the regional economies has largely been driven by trade. The trade structure in the economy has been constantly upgraded in order to implement the so-called export-oriented development strategy, presumably because of the pressure from market competition. The past experience of the regional economy shows that changes in exchange rates affect both trade development and shifts in trade structure. Figure 14.1 illustrates that trade growth of the East Asian economy has closely followed the trend of the composite exchange rate- with slight time lags-over the past 30 years.

Exchange rate misalignments can trigger structural changes. Most East Asian developing economies pegged their currencies to the US dollar in recent years, even though their trade with the United States accounted for only a proportion of their total trade. Consequently, changes in the nominal and real value of the US dollar relative to the Japanese yen may have affected the real exchange rate of those Asian currencies pegged to the US dollar. For example, when the yen was strong against the US dollar, Asian currencies pegged to the US dollar tended to depreciate relative to the yen. There are two effects. First, a strong yen against the US dollar tended to increase the international competitiveness of East Asian exports, especially in the US market. Second, a strong yen forced Japan to shift production facilities offshore in the form of foreign direct investments, benefiting other East Asian economies in their production upgrading. Consequently, the period under study can be divided into two phases: one associated with a strong yen and the other with a weak yen. The impact on competitiveness and capital flows in the regional economy can be discussed accordingly.

A large-scale exchange rate misalignment, coupled with factors such as inappropriate macroeconomic policies, can provoke a financial crisis such as the East Asian crisis. In the case of a weak yen, a real exchange rate appreciation tends to reduce the competitiveness of the regional economy, worsening the current accounts of the individual economies and endangering export-oriented development strategy, necessitating drastic policy measures to restore the external balance.

Due to a financial deregulation and liberalisation program aimed at opening up capital markets, a pegged system could provoke capital inflows because of the low exchange rate risk associated with a policy of stable currency value. Such inflows prevent currency depreciation, causing large and growing current account imbalances. 
The changes in East Asian exchange rates against the US dollar in nominal terms are depicted for the period 1971 to 1995 in Figure 14.2. For convenience, the NIEs and ASEAN countries are grouped together. There were four major appreciations of the yen against the US dollar during the period under study, beginning in 1971, 1975, 1985 and 1991, respectively. Each swing lasted for at least 3 years. Such medium-term swings in nominal exchange rates - referred to as misalignments-can lead to changes in real exchange rates (Marston 1991:125).

As argued earlier, from the perspective of other East Asian economies, there are some benefits associated with a strong yen, such as improved competitiveness and large capital inflows, mainly from Japan. These effects, along with others such as a more favourable international economic climate in the early years, became the driving force for structural change and adjustment in these economies.

The first appreciation of the yen in 1971 was associated with a shift of production facilities-especially those which produced labour-intensive products - from Japan to other economies in East Asia, particularly Korea and Taiwan. Imports of capital-intensive products from Japan by ASEAN and the NIEs peaked during this period ( 41.8 and 47.5 per cent respectively), laying a

Figure 14.1 Changes in East Asian exchange rate (composite) and trade growth, 1966-96 (per cent)

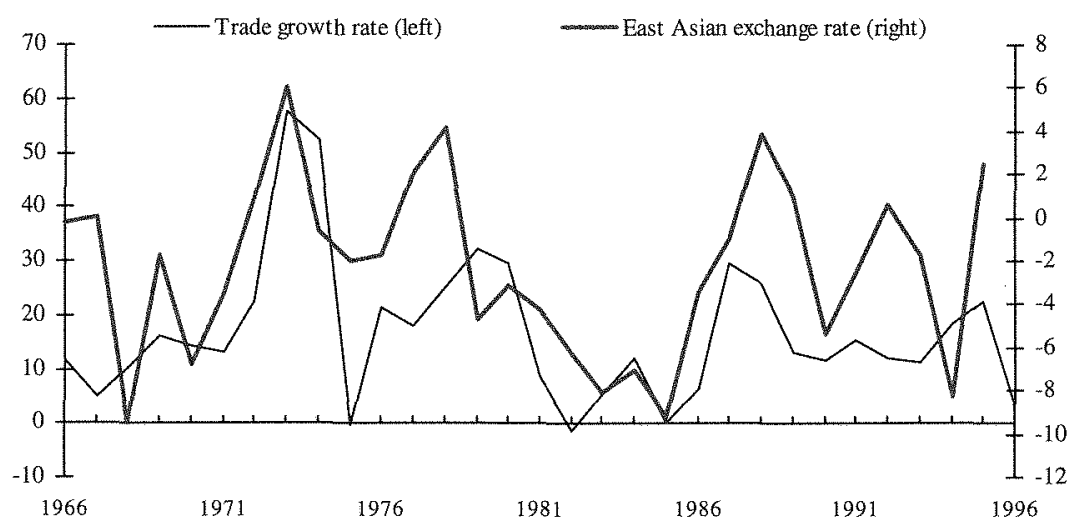

Notes: East Asian economy includes Japan, China, Hong Kong, Taiwan, Korea and ASEAN countries (5). Trade growth rate is calculated based on these economies as a whole. The composite exchange rate was formed by calculating the average changes of the respective exchange rates against the US dollar (nominal) using total trade of each as weights.

Source: United Nations' COMTRADE International Trade Data, October 1997, International Economic Databank, The Australian National University, Canberra; authors' calculations. 
foundation for carrying out the export-oriented development strategy in these economies. ${ }^{1}$ Exports had become an important source of economic growth, and a major goal of governments with respect to exchange rate policy had been to prevent their currencies from appreciating since appreciation would be detrimental to the export-oriented growth.

Exchange rate misalignment of the yen/dollar continued into the $1980 \mathrm{~s}$. Beginning in 1985, the yen began a sharp appreciation against other currencies, particularly the US dollar. As pointed out by Petri (1991:51), this round of appreciation was roughly twice as large as that in 1971-73 (Figure 14.2), and therefore had an even stronger effect on the structural changes associated with capital flows and changing competitiveness of the regional economy.

As the relative cost of production in Japan increased with protectionist measures directed against exports from Japan, there were massive flows of capital from Japan to the East Asian economies, particularly the NIEs and ASEAN. Through these, Japan built stronger economic and trade relationships first with the NIEs, then ASEAN and later China, and accelerated the pace of structural changes in the regional economy. The trade relationship was characterised by Japan's export of advanced consumer goods and-especially in the case of

Figure 14.2 Changes in the East Asian exchange rate against the US dollar (per cent)

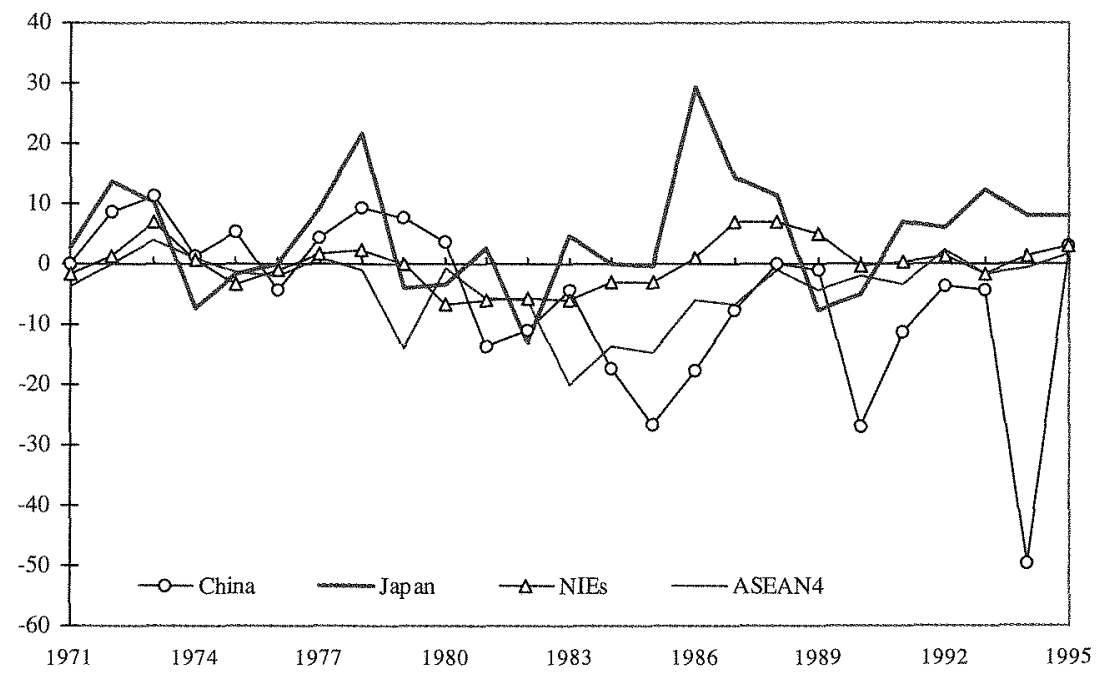

Source: The World Bank; United Nations' COMTRADE International Trade Data, October 1997, International Economic Databank, The Australian National University, Canberra and authors' calculations. 
NIEs-capital goods and sophisticated components, and its imports of consumer goods - at both ends of the quality spectrum - and industrial supplies (Petri 1991:77).

There were also periods in which a weak yen relative to the US dollar, negatively affected the process of East Asian structural transformation. For example, from the late 1970s to mid-1980s, the yen consistently depreciated against the dollar. Since most East Asian exports at that time went to destinations outside the region, other East Asian economies were forced to depreciate their currencies to maintain international competitiveness. ${ }^{2}$

A weak yen combined with the forced depreciation of other regional currencies restrained these economies' imports. This slowed the progress of their industrial upgrading, offseting the gains in competitiveness resulting from currency depreciation. After the loss of export momentum of the East Asian economies, the regional economy was dragged into recession in the early 1980 s. $^{3}$

There is a unique relationship between economic growth of the East Asian economies and the yen/dollar exchange rate in that there is a high correlation (0.68) between GDP growth of the East Asian economies (excluding Japan) and changes in the exchange rate between the yen and US dollar. A simple Granger causality test indicates that the exchange rate Granger-causes' GDP growth and the reverse does not hold for this case. ${ }^{4}$ This is consistent with the story that exchange rate movements - not only regional currencies against major currencies such as US dollar and Japanese yen, but especially between major currencies such as the US dollar vis-à-vis the yen - do have a significant impact on economic growth through their influence on both capital flows and export competitiveness.

\section{EAST ASIAN COMPETITIVENESS AND BALANCE OF TRADE}

The extent to which exchange rate changes affect a country's export competitiveness depends on how its real exchange rate is affected. It is the real exchange rate that affects the allocation of productive resources in the economy. Faced with a strong yen since the mid 1980s, most East Asian economies adopted a strategy of pegging their currencies to the US dollar in order to maintain currency stability.

Unfortunately, from 1995 the US dollar appreciated sharply against the yen (the yen/dollar exchange rate rose from 80 in 1995 to approximately 125 in 1997). As a result, East Asian currencies that were tied in nominal terms to the dollar also experienced a very rapid real appreciation, causing a substantial loss of export competitiveness, especially for Thailand, Malaysia, Indonesia and the Philippines (Figure 14.4). 
Some of the Northeast Asian economies-such as Hong Kong, Korea and Taiwan-also experienced a decline in export competitiveness after 1995 (Figure 14.5). China stands out in comparison with other East Asian economies in that its competitiveness took several jumps (Figure 14.5) after a number of depreciations during the previous 15 years (Figure 14.2). But after peaking in 1994 due to the large-scale depreciation resulting from the exchange rate system reform of that year, China's competitiveness began to decline.

The declining trend of East Asian economies' export competitiveness in the mid 1990s is reflected in East Asia's balance of trade (Table 14.1). The figures reveal that the trade balance of the East Asian economies as a whole witnessed a structural change during the decade 1986-96. First, there was a widening trade imbalance (deficits) within the East Asian economies (first column), reflecting the rapid development of intraregional trade on the one hand and unbalanced trading relations among themselves, on the other.

Second and more significantly, in 1996, the East Asian economies-for the first time-incurred trade deficits with countries outside the region (second column), confirming that the region's overall competitiveness had deteriorated.

Figure 14.3 Changes in yen/US dollar exchange rate and East Asian GDP growth, 1970-98 (per cent)

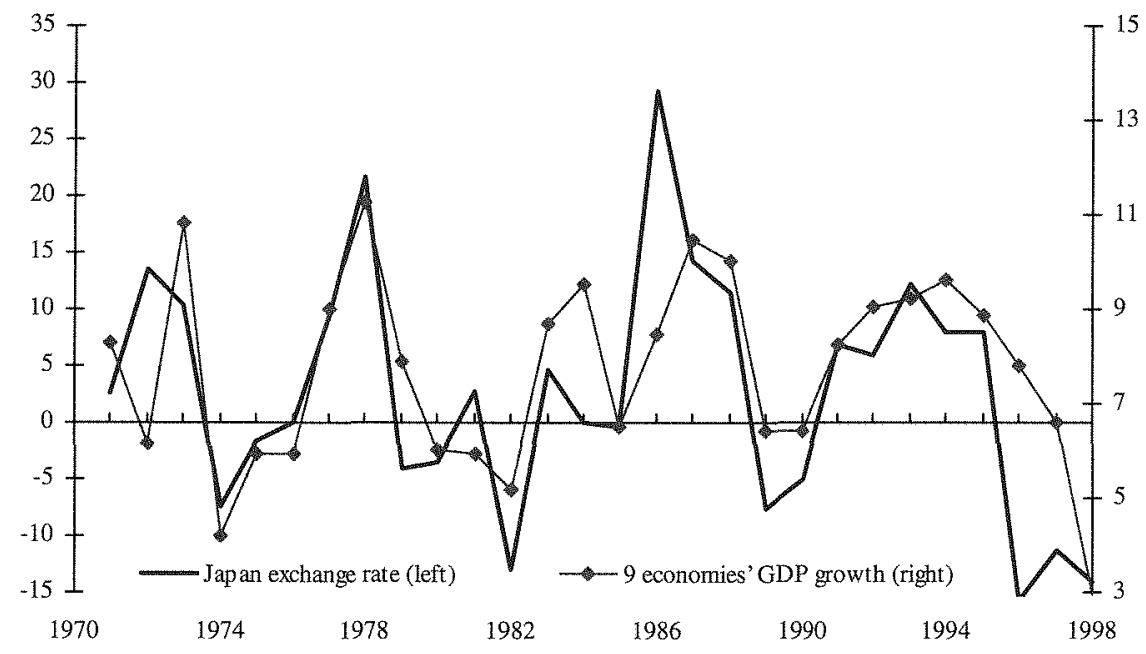

Note: GDP figures for nine East Asian economies are calculated based on the constant price of US dollar of 1987.

Source: The World Bank; World Tables, International Economic Databank, The Australian National University, Canberra; authors' calculations. 
This drastic shift in the trade balance of the regional economy may underly the causes of the financial crisis that began in 1997.

The slowdown in export revenue led to expectations of reduced corporate profits and to a decline in equity prices (Noland 1998). First domestic residents, then foreign investors, began moving money offshore in search of higher returns, contributing to exchange rate depreciation (in countries with a floating currency), or alternatively, putting pressure on the exchange rate peg (in countries that pegged to a foreign currency such as the dollar). The rest of the story is well known.

Third, while the East Asian economies still enjoyed a trade surplus-albeit a declining one - with the United States, trade with the Western European countries and the world as a whole created emerging deficits in 1993 and 1994, when both NIEs' and ASEAN's nominal exchange rates showed signs of appreciation against the US dollar (Figure 14.2) and their export competitiveness began to decline (Figures 14.4 and 14.5).

Finally, large deficits for trade within the East Asian region, and the surplus with the United States reveal an interesting triangular trade relationship between the East Asian economies, Japan and the United States. Park and Park (1991) describe this relationship by examining the case for NIEs. These economies depended on the US market for their exports of manufactured products and relied heavily on Japan as a major supplier of capital goods, intermediate inputs, technology and management know-how. These patterns of trade led to a growing trade surplus with the United States and a large and persistent deficit with Japan, both of which began in the early 1970s (Park and Park 1991:85).

More importantly, this pattern of trade is often identified as one of the structural rigidities hindering adjustment of the trade imbalance between the NIEs and the United States on the one hand, and between the NIEs and Japan on the other (Park and Park 1991:85). These rigidities have been perpetuated and complicated by constant changes in the product composition of exports of the East Asian economies, driven by their underlying comparative advantage.

\section{TRADE COMPOSITIONAND STRUCTURAL CHANGE}

The structural changes which have been taking place in East Asia are clearly reflected in the changing pattern of their exports of labour-intensive products. Figure 14.6 reports the shares of East Asian economies' total exports of labourintensive products to the United States during the past three decades (1965-95), which can roughly be divided into three sub-periods.

From the mid-1960s to the mid-1970s, exports of labour-intensive products from Japan were predominant in the United States import market. Hong Kong was also a big player during this period. Other economies as a whole had a very small-though increasing - share in the US market for labour-intensive products, particularly Taiwan and Korea. 
Figure 14.4 Real exchange rate for Southeast Asian economies, 1975-98

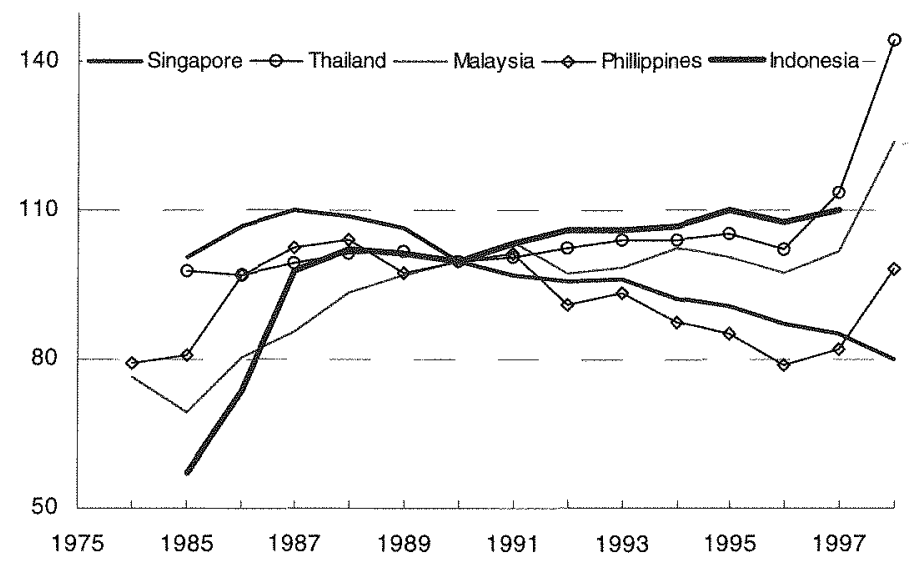

Note: $\quad 1990=100$.

Source: International Monetary Fund various issues, International Financial Statistics, Intemational Economic Databank, Asia Pacific Economics Group, Asia Pacific Profiles 1998, The Australian National University, Canberra.

Figure 14.5 Real exchange rate for Northeast Asian economies, 1975-98

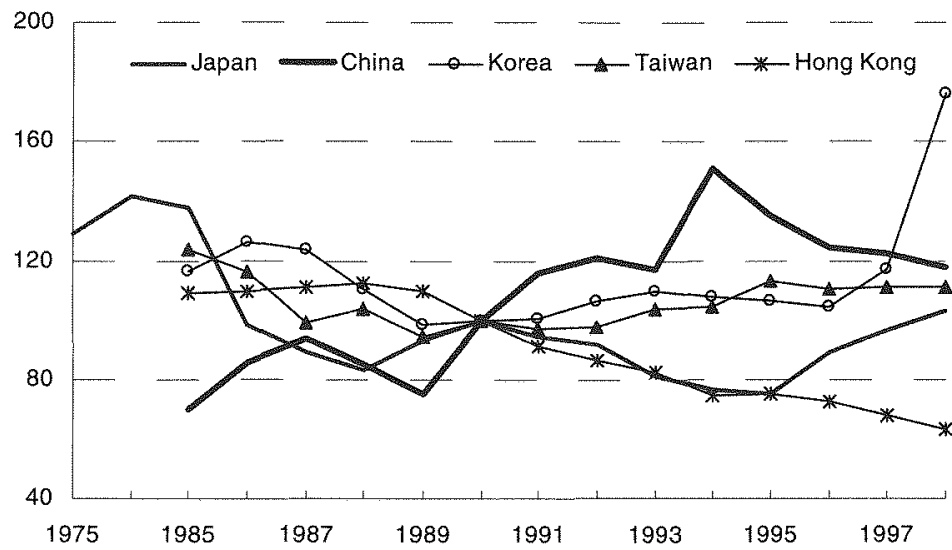

Note: $\quad 1990=100$.

Source: International Monetary Fund various issues, International Financial Statistics, International Economic Databank, Asia Pacific Economics Group, Asia Pacific Profiles 1998, The Australian National University, Canberra. 
Table 14.1 East Asian balance of trade, 1986-96 (US\$ billion)

\begin{tabular}{llrlrr}
\hline Year & $\begin{array}{c}\text { Within } \\
\text { East Asia }\end{array}$ & $\begin{array}{c}\text { Outside } \\
\text { East Asia }\end{array}$ & $\begin{array}{c}\text { With the } \\
\text { United States }\end{array}$ & $\begin{array}{c}\text { With } \\
\text { West Europe }\end{array}$ & $\begin{array}{c}\text { With } \\
\text { the World }\end{array}$ \\
\hline 1986 & -10.10 & 104.81 & 86.88 & 20.62 & 94.71 \\
1987 & -17.06 & 102.22 & 87.92 & 24.31 & 85.16 \\
1988 & -22.89 & 85.15 & 76.40 & 27.43 & 62.26 \\
1989 & -27.55 & 56.60 & 68.15 & 19.85 & 29.05 \\
1990 & -28.05 & 29.95 & 54.93 & 17.28 & 1.90 \\
1991 & -38.80 & 41.95 & 49.00 & 26.27 & 3.15 \\
1992 & -48.97 & 58.95 & 57.38 & 24.06 & 9.98 \\
1993 & -68.35 & 58.13 & 69.82 & 9.75 & -10.22 \\
1994 & -63.45 & 45.15 & 76.14 & -4.36 & -18.30 \\
1995 & -69.93 & 6.80 & 58.81 & -12.10 & -63.13 \\
1996 & -80.22 & -39.49 & 41.61 & -23.46 & -119.71
\end{tabular}

Notes: East Asia consists of 10 economies; outside East Asia includes the United States and West Europe. Trade deficits within East Asia also include Hong Kong's trade deficit with China.

Source: UN trade data, International Economic Databank, The Australian National University, Canberra.

From the mid-1970s to the late 1980s, Japan's share of labour-intensive products in the US market shrank rapidly, while the shares of Taiwan and Korea expanded substantially. Hong Kong's share also expanded, but showed signs of declining from the early 1980s. This declining trend occurred in Hong Kong earlier than in Taiwan and Korea, presumably because of Hong Kong's closer integration with mainland China.

Singapore also enjoyed an enlarged share compared with the previous period, but still much lower than that of Japan, Hong Kong and China. ASEAN's shares started picking up, though from a very low base.

From the end of the 1980s to the mid-1990s, the Asian NIEs--following in the footsteps of Japan-reduced their shares of labour-intensive exports in the US market. ASEAN countries increased their shares rapidly in the early period and maintained a relatively constant share from the beginning of the 1990s. Among these East Asian economies, China became a predominant player in exporting labour-intensive products to the US market.

Finally, East Asia's share of labour-intensive exports to the United States peaked by the early 1980 s, reaching nearly 70 per cent of total imports of labourintensive products by the United States. Its share declined steadily through the mid 1990s. By 1995, the overall share was almost equivalent to that in 1965, implying that the product composition of exports of the East Asian economies as a whole has shifted from predominantly labour-intensive products to capital and even human-capital intensive products over the period. 
Figure 14.6 East Asian share of labour-intensive products in US market, 1965-95 (per cent)

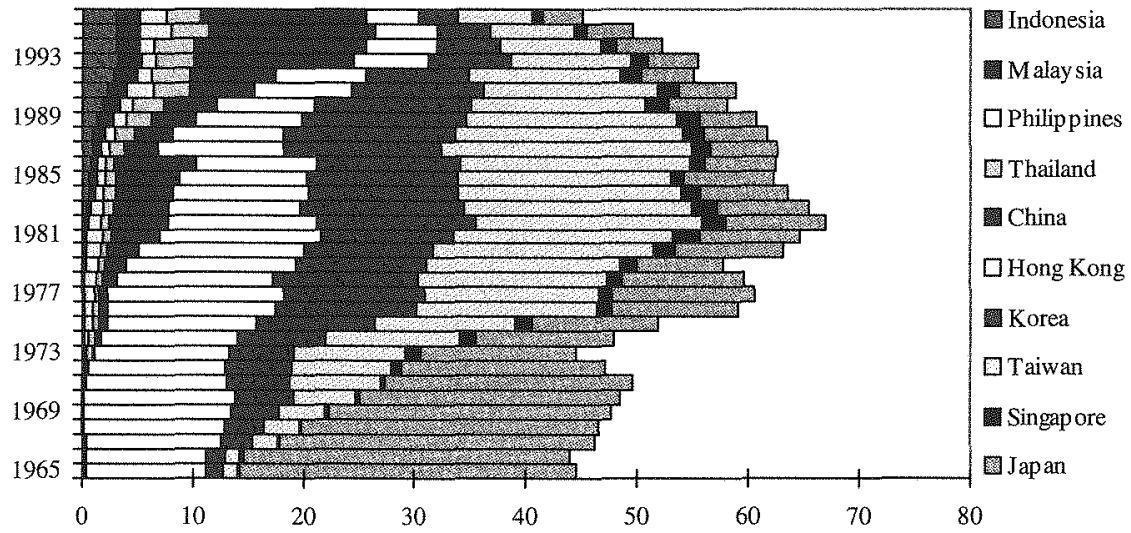

Source: STARS: UN COMTRADE International Trade Data, October 1997, International Economic Databank, The Australian National University, Canberra.

Figure 14.7 Product structure of East Asian exports to the United States, 1965-95 (per cent)

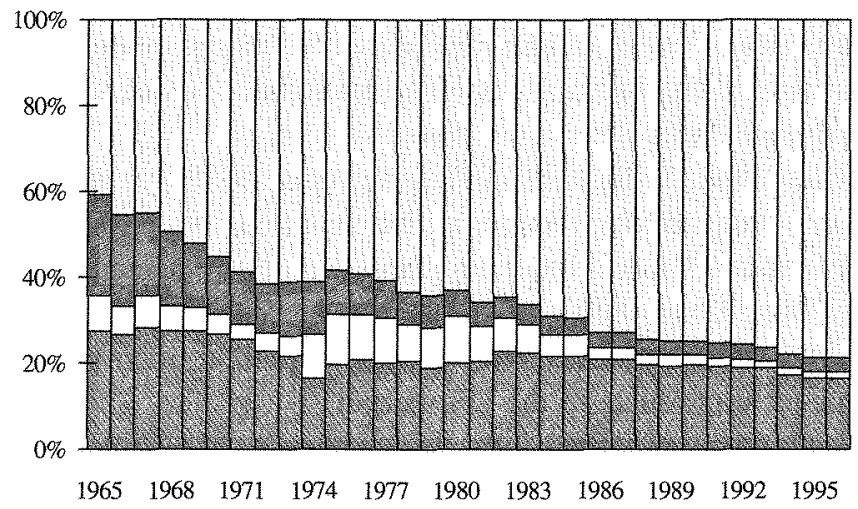

9 CAPITAL

圈 AGRICULTURE

MINERALS

LABOUR

Source: STARS: UN COMTRADE International Trade Data, October 1997, International Economic Databank, The Australian National University, Canberra. 
However, the pressure from competition has not been lessened by the shifts of product composition of exports, particularly among those economies with similar factor endowments and who are at similar stages of development. For example, since traded goods from China and ASEAN countries are highly homogenous, competition between them in third country markets is inevitable.

Growth rates of exports of labour-intensive products of the ASEAN 4 over the period 1986-96 peaked from the mid 1980s to the early 1990s (Table 14.2). By 1996, two economies-Thailand and the Philippines-even recorded negative growth. At the same time, China has become a large exporter of labour-intensive products.

A solution to this competition problem seems to be that the East Asian economies need to be constantly upgrading their production to raise the product sophistication of their exports. This is what Japan did in the 1960s and 1970s, the NIEs did in the 1970s and 1980s, and what ASEAN and China have been doing since the late 1980s and early 1990s (Figure 14.7).

The share of capital-intensive products in the East Asian economies' total exports to the US market increased substantially, while the shares of agriculture, minerals and labour-intensive products were falling over this period. However, in order to see how industrial transformation (upgrading) was taking place in the regional economy, we need to look at how trade structures - for example, with respect to capital-intensive products-of the regional economies with different levels of development evolve over time. The ASEAN 4 and NIEs are chosen here to see how their trade orientation of capital-intensive products with

Table 14.2 Growth rates of exports of labour-intensive products of ASEAN 4, 1986-96 (per cent)

\begin{tabular}{lrrrr}
\hline Year & Indonesia & Malaysia & Philippines & Thailand \\
\hline 1986 & 45.47 & 15.34 & 10.40 & 37.00 \\
1987 & 34.38 & 44.76 & 30.85 & 64.63 \\
1988 & 51.23 & 20.38 & 24.85 & 36.57 \\
1989 & 44.40 & 32.49 & 24.64 & 28.08 \\
1990 & 58.28 & 35.98 & 12.12 & 20.95 \\
1991 & 46.12 & 29.75 & 98.55 & 27.40 \\
1992 & 42.46 & 19.87 & -37.32 & 9.42 \\
1993 & 9.53 & 1.80 & 5.88 & 16.86 \\
1994 & -1.72 & 16.48 & 13.76 & 11.55 \\
1995 & 10.43 & 18.31 & 93.22 & 21.78 \\
1996 & 7.73 & 10.88 & -1.26 & -36.72
\end{tabular}

Source: STARS: UN COMTRADE International Trade Data, October 1997, International Economic Databank, The Australian National University, Canberra. 
other groups of the East Asian economy and the United States has changed over the past decade (Table 14.3).

First, while their dependence on capital-intensive imports from the East Asian region was similar, ASEAN's dependence on capital-intensive exports to the East Asian market was higher than that for NIEs.

Second, both ASEAN and NIEs' export dependence on capital-intensive products to the East Asian region increased substantially, while their dependence on the US market dropped over the period. This may indicate that both groups suffered a reduction in US market share similar to the situation for labourintensive products in previous periods (Figure 14.6).

Third, both groups continued to rely heavily on imports of capital-intensive products from Japan. Although the dependence ratio was declining over this period - particularly for NIEs - it is still much higher than that of imports from the United States. It is also noted that ASEAN countries are rapidly depending on NIEs to provide capital-intensive products. This may reflect that NIEs are catching up quickly in producing more sophisticated capital-intensive products.

Fourth, for exports of capital-intensive products, both groups depend more on the United States; for imports, they both rely more on Japan. This confirms that the pattern of a triangular trade relationship between the East Asian economies, Japan and the United States identified earlier still exists. This also means that future East Asian trade will continue to be affected by the movement of the yen/ US dollar exchange rate.

Table 14.3 Trade orientation of capital-intensive products by ASEAN 4 and NIEs, 1986 and 1996 (per cent)

\begin{tabular}{llrrrr}
\hline & \multicolumn{2}{c}{ Exports } & \multicolumn{2}{c}{ Imports } \\
& & 1986 & 1996 & 1986 & 1996 \\
\hline \multirow{2}{*}{ ASEAN4 } & & & & \\
& East Asia & 43.36 & 54.30 & 51.56 & 60.02 \\
& NIEs & 26.78 & 32.72 & 13.65 & 22.30 \\
& ASEAN & 5.42 & 7.55 & 2.26 & 4.82 \\
& China & 2.01 & 1.46 & 1.19 & 1.91 \\
& Japan & 9.15 & 12.57 & 34.47 & 30.98 \\
& United States & 33.61 & 23.06 & 19.27 & 15.98 \\
& East Asia & 26.31 & 47.57 & 58.20 & 59.78 \\
& NIEs & 8.94 & 18.20 & 8.11 & 12.49 \\
& ASEAN & 7.65 & 15.65 & 4.01 & 10.30 \\
& China & 2.58 & 4.98 & 3.98 & 10.11 \\
& Japan & 7.14 & 8.74 & 42.09 & 26.88 \\
& United States & 44.05 & 22.66 & 18.78 & 18.67
\end{tabular}

Source: STARS: UN COMTRADE International Trade Data, October 1997, International Economic Databank, The Australian National University, Canberra. 
Finally, structural changes in the East Asian economies are also reflected in their changing industrial structure (Table 14.4). The shares for manufacturing industry have been declining gradually in Japan and Singapore and sharply in Hong Kong. At the same time, the shares for the services industry have steadily increased over the past decade.

\section{LESSONSAND POLICYIMPLICATIONS}

The problem with the East Asian economy now is that shocks arise from both goods and capital markets. The former type of shock is mainly due to the reduction in export competitiveness, caused at least in part by the appreciation of their real exchange rates. The other shock largely results from countries' overborrowing, the misconduct of government policy which contributed to the 'bubble economy' and weak financial and banking systems.

A long-term strategy for resolving the crisis is industrial upgrading. This strategy requires further accumulation of a country's physical and human capital and secure external markets for its exports. Since the triangular trade and investment relationship between Japan, the United States and other East Asian economies will remain unchanged for some time to come, it is important for both Japan and the United States to stabilise exchange rates, stimulate economic growth (for Japan) and keep markets open to exports from the East Asian economies.

Even with some justification for imposing capital (or exchange) controls as an extraordinary measure adopted to deal with the crisis, countries in the region should try to continue to strive towards an open market for goods, services and capital in the ongoing process of liberalisation.

For China, the general consensus is that keeping the renminbi exchange rate unchanged throughout the financial crisis contributed to the stability of the regional economy by preventing regional economies from plunging into a new wave of competitive depreciation. But the government should not renounce exchange rate adjustments as a policy instrument for dealing with macroeconomic (external) imbalances.

The flexible exchange rate policy adopted by the government has contributed greatly to the remarkable achievements in external trade by China in the process of trade liberalisation. This is because, as Edwards (1995:10) points out, 'real exchange rate behaviour is a key element during a trade liberalisation transition'.

Competition from other crisis-hit economies in East Asia may intensify at later stages when liquidity problems in these economies are overcome and the elasticities of supply of exports rise.

Without devaluation, the only choice left for the government to maintain export competitiveness is to raise productivity, which arises through more efficient 
Table 14.4 Changing industrial structure of Japan and NIEs, 1986 and 1994 (per cent)

\begin{tabular}{|c|c|c|c|c|c|c|c|c|}
\hline \multirow[t]{2}{*}{ Country } & \multicolumn{2}{|c|}{ Agriculture } & \multicolumn{2}{|c|}{ Industry } & \multicolumn{2}{|c|}{ Manufacture } & \multicolumn{2}{|c|}{ Service } \\
\hline & 1986 & 1994 & 1986 & 1994 & 1986 & 1994 & 1986 & 1994 \\
\hline Japan & 3.0 & 2.1 & 40.3 & 38.2 & 28.6 & 24.5 & 56.7 & 59.6 \\
\hline Hong Kong & 0.4 & 0.2 & 30.3 & 16.9 & 22.6 & 9.3 & 69.2 & 83.0 \\
\hline Singapore & 0.6 & 0.2 & 37.4 & 35.3 & 26.4 & 26.1 & 61.9 & 64.6 \\
\hline Taiwan & 5.5 & 3.6 & 47.1 & 37.4 & 39.4 & 29.0 & 47.3 & 59.1 \\
\hline Korea & 11.2 & 7.0 & 42.1 & 42.8 & 30.8 & 26.8 & 46.8 & 50.1 \\
\hline
\end{tabular}

Source: STARS: UN COMTRADE International Trade Data, October 1997, International Economic Databank, The Australian National University, Canberra.

allocation of productive resources. Of course, policy measures such as increasing the export tax rebate and provision of export credit, will certainly be helpful in boosting exports, but they are not long-term solutions to the problems facing China's external sector. As previous experience shows, the more efficient allocation and use of productive resources in the export sector of the economy follows from ongoing trade system reform and liberalisation. It is therefore in China's fundamental interests to continue its reform and liberalisation program.

A similar argument on the importance of an export-oriented development strategy for developing economies can be made from another angle. Attracting foreign capital has proved to be an effective means of acquiring much-needed new technology and skills, thereby upgrading industrial structure and raising productivity. China, with its big plans to attract and utilise more foreign capital in its economic transformation, is no exception in this regard. A firm commitment to reform and liberalisation will secure business confidence, thereby attracting more foreign capital into the economy.

\section{CONCLUSIONS}

Exports have contributed greatly to the economic growth and prosperity of the East Asian economies in the past, but a slowdown of export growth also helped trigger the financial crisis which wiped out so many of the gains from trade for these economies. They may have to reply with a strategy to 'export their way out' of the crisis. This strategy is not without its risks.

Uncertainties associated with this strategy include exchange rate volatility, capital outflows, export financing (liquidity problem), intensified competition (due to the wide spread depreciations), protectionism, and a slowdown of economic growth in other parts of the world economy, particularly North America and Europe. 
The triangular relationship between the East Asian economies, Japan and the United States facilitated the rapid economic transformation in the East Asian economies in the past, but due to structural rigidities, also imposed some limits to the export-oriented development strategy of the East Asian economies. Resolving the current difficulties requires cooperation from all parties involved. In particular, the opening of markets is essential for the recovery of the regional economy and for the stability and security of the Asia Pacific region.

It is in this context that the continued global (WTO) as well as region-wide trade liberalisation (APEC) seems to hold the key to long-term solutions. It is particularly important for the East Asian economies, since they are heavily dependent on intra-regional trade. China has been less disrupted by the financial crisis and therefore may be able to play a more positive role in maintaining the momentum of region-wide trade liberalisation (APEC).

\section{REFERENCES}

Das, D.K., 1998. 'Changing comparative advantage and the changing composition of Asian exports', The World Economy, 21(1):121-40.

Dornbusch, R. and Leslie, F. and Helmers, H.C. (eds), 1988. The Open Economy: Tools for Policymakers in Developing Countries, Oxford University Press, New York and Oxford.

Edwards, S. (ed.), 1995. Capital Controls, Exchange Rates and Monetary Policy in the World Economy, Cambridge University Press, Cambridge.

Garnaut, R., 1998. 'The financial crisis', Asian-Pacific Economic Literature, 12(1):1-11.

Marston, R.C., 1991. 'Price behaviour in Japanese and US manufacturing' in P. Krugman (ed.), Trade with Japan: Has the Door Opened Wider?, University of Chicago Press, Chicago and London.

Noland, M., 1998. Statement before the House International Relations Committee Subcommittees on Asian and Pacific Affairs, and International Economic Policy and Trade, Washington, DC, 3 February.

Park, Y.C. and Park, W., 1991. 'Changing Japanese trade patterns and the East Asian NICs' in P. Krugman (ed.), Trade with Japan: Has the Door Opened Wider?, University of Chicago Press, Chicago and London.

Petri, P.A., 1991. 'Market structure, comparative advantage, and Japanese trade under the strong yen' in P. Krugman (ed.), Trade with Japan: Has the Door Opened Wider?, University of Chicago Press, Chicago and London.

Song, L., 1996. Changing Global Comparative Advantage: Evidence from Asia and the Pacific, Addison-Wesley, Melbourne. 


\section{NOTES}

1 As a result, Japan's share of exports of labour-intensive products in the US market fell dramatically in the early 1970s and the shares for Taiwan and Korea picked up (Figure 14.6).

2 The most recent episode of a weak yen was during the period from 1995 to the present. This swing of the yen/dollar exchange rate has lasted more than three years and has been accompanied by a deterioration of the Japanese economy, and the financial crisis in East Asia.

3 This was one of the reasons why a weakened yen against the US dollar towards mid-1998 was so worrisome for the regional economies.

4 The computed $F$ value (9.11) exceeds the critical $F$ value $(7.82)$ with $(1,24)$ degree of freedom at the 1 per cent level of significance, so that the null hypothesis is rejected. 